\title{
Immune Augmentation of Injectable PLGA-Dextran (PLDEX) a Double Polymeric Microspheres as an Adjuvant for Hepatitis B Vaccine
}

\author{
Sivakumar Sivagurunathan Moni $^{{ }^{*}}$, Sukumaran Natarajapillai ${ }^{2}$, Mohammed M. Safhi ${ }^{3}$ \\ ${ }^{1}$ Department of Pharmaceutical Microbiology, College of Pharmacy, Jazan University, Jazan, Kingdom of Saudi Arabia; ${ }^{2}$ School of \\ Life Sciences, Vel's University, Pallavaram, Chennai, India; ${ }^{3}$ Department of Pharmacology, College of Pharmacy, Jazan University, \\ Jazan, Kingdom of Saudi Arabia. \\ Email: *drsmsivakumar@gmail.com
}

Received February 25 $5^{\text {th }}, 2011$; revised April $2^{\text {nd }}, 2011$; accepted May $10^{\text {th }}, 2011$.

\begin{abstract}
A new method has been developed to prepare microspheres by blending PLGA and dextran polymers (PLDEX) using solvent evaporation technique. Recombinant hepatitis B vaccine (HBsAg) was incorporated in to the double polymeric system. The objective of this study was to investigate the feasibility of PLDEX polymeric microspheres as an adjuvant for hepatitis B vaccine (HBsAg). The present study demonstrates the immunogenicity profile of HBsAg encapsulated in PLDEX and compared their efficacy with alum adsorbed HBsAg. The single intramuscular injection of HBsAg loaded PLDEX microspheres in Wistar rats resulted satisfactory antibody titers. Based on in vivo findings PLDEX microspheres were able induce satisfactory immune response.
\end{abstract}

Keywords: HBsAg, PLGA—Dextran Microspheres, Vaccine Delivery, Immunogenicity

\section{Introduction}

Hepatitis B is an acute systemic infection, which turn into a major public health problem all over the world [1]. Hepatitis B virus infection can lead to fulminant hepatic failure (FHF), which acutely threatens the life of affected patients Approximately, 30\% of world's population has serological evidence of hepatitis B virus infection [2]. It is estimated that 350 million of them chronic hepatitis B infection, about a million of which die every year from chronic liver disease, including cirrhosis and liver cancer. Hepatitis B infection is an important cause of morbidity and mortality after kidney transplantation. Progressive liver disease affects more than $80 \%$ of HBsAg positive renal transplant recipients. Hepatitis B virus is the major cause of hepatocellular carcinoma worldwide next to tobacco a known human carcinogen [3]. The liver disease associated with hepatitis B infection results largely from the immune response to the virus. In seeking to kill the virus, the immune system damages the liver cells due to virus multiplication. Chronically infected persons called carriers are easily develop cirrhosis and liver cancer $[4,5]$.
The diagnosis of acute hepatitis B infection is confirmed by detection of the surface antigen and IgM antibody to the core antigen. The presence of HBeAg is indicative of an exceptionally high inoculum and active viral replication. Patients with chronic hepatitis B infection have persistence of the surface antigen in the serum and liver tissue. Mutation in the HBV genome has frequently been detected during persistent viral infection. The development of anti HBs indicates immunologic response to infection and cure. Hepatitis B vaccine has been available for over 3 decades. The World Health Organization has recommended that hepatitis B vaccination should be included in routine immunization for all children worldwide. As a result, various immunization strategies have been developed for routine infant vaccination, prevention of perinatal transmission and catch up vaccination for old age groups. Currently available heaptitis B vaccines are immunogenic, efficacious and safe but it requires multiple recall injection at approximate time intervals usually given at 0,1 and 2 months or 0,1 and 6 months. The multiple vaccination schedule may leads to drop out due 
to economical crisis, social, cultural inconsistency to the use of syringes and increasing age also declines the immune response. A more immunogenic vaccine may also enable a reduction in the number of injections in order to combat the social and cultural resistance to the use of syringes for long term protection against hepatitis B virus infection. Adjuvants and antigen delivery systems are essential in inducing and modifying immune responses [6]. Delivering effective and safe vaccines through an efficient delivery system is one of the most cost effective health arbitrations. Therefore, the development of newer vaccine delivery system, both more efficacious and easier to deliver, has an area of research that can certainly benefit from controlled release technology using biodegradable polymers. PLGA has become a primary candidate for the preparation of sustained release vaccines. Burst effect is the common obstacle related to PLGA polymeric system and some of the earlier reports have demonstrated novel approach to prevent burst release of antigen from PLGA microspheres [7]. In order to modify the burst effect, in this research work PLGA and dextran polymers were blended (PLDEX) and thus double polymeric microspheres were prepared. In order to investigate the feasibility of a single shot PLDEX microspheres loaded with hepatitis B vaccine, various parameters were established in this present study. However, the present report demonstrates the immunogenicity profile of HBsAg encapsulated in PLDEX polymer and compared their efficacy with alum adsorbed HBsAg.

\section{Materials and Methods}

Poly (D, L)-lactide-co-glycolic acid (PLGA) with a lactide/glycolide (L/G) ratio of 50/50 (Mw 50 KDA, inherent viscosity $0.67 \mathrm{dl} / \mathrm{g}$, polyvinyl alcohol (PVA, 87\% 89\% hydrolysed), Dextran (Mw 70,000) and dicloromethane were purchased from Sigma Aldrich, USA. Recombinant hepatitis B surface antigen (alum free) and alum adsorbed hepatitis B vaccine were obtained as a free sample from Serum Institute of India, Pune. HBsAg encapsulated PLDEX microspheres was prepared by solvent evaporation technique. The immune response studies were carried out in healthy Wistar rats, which were maintained and handled according to the standard guidelines. The immunogenicity studies were carried out by antibody induction method. 42 healthy Wistar rats (150 - 250 gms) were selected for this study and they were divided in to 7 groups. Each group containing 6 Wistar rats and housed in a separate microlon boxes (Torson products, Kolkata) for the purpose of acclimatization. The size of the animal box is $45 \times 27 \times 15 \mathrm{~cm}$. They had free access to water and standard pellet diet throughout the study. The immune response was determined by measuring specific antibodies and immunoglobulin levels. All the animals were received $0.5 \mathrm{ml}$ of vaccine having $2 \mu \mathrm{g}\left(1 / 10^{\text {th }}\right.$ of standard human dose) injected intra muscularly and some of the groups received booster dose 4 weeks after primary immunization. The various treatment groups are:

Group 1-Immunized with a single dose of hepatitis B vaccine encapsulated PLDEX microspheres.

Group 2-Immunized with hepatitis B vaccine encapsulated PLDEX microspheres as primary dose and the same as booster dose.

Group 3-Immunized with hepatitis B vaccine encapsulated PLDEX microspheres as primary dose and conventional alum adsorbed hepatitis B vaccine as booster dose.

Group 4-Immunized with a single dose of alum adsorbed hepatitis B vaccine.

Group 5-Immunized with alum adsorbed hepatitis B vaccine as primary dose and the same as booster dose

Group 6-Control animals (without vaccines).

Group 7-Control samples with dummy PLDEX microspheres.

The quantitative measurement of anti HBs was determined using Immulite 2000 automated analyzer (Diagnostic products corporation, CA) and the IgG, IgA and IgM were determined by Turbox IgG, IgA and IgM assay (Orion Diagnostica). The IgE level was analyzed by Immulite 2000 IgE analyzer. The values were analysed by statistical comparisons using one way ANOVA. The level of significance was taken as $p<0.05$. Dunnet multiple comparison tests were performed to find out the level of significance.

\section{Results and Discussion}

The development of new vaccines, both more efficacious and easier to deliver, has become an area of research that can certainly benefit from microencapsulation technology. Specifically, the conversion of multiple dose vaccines in to single dose vaccines may represent an important advancement towards the betterment of human health care and welfare. The development of vaccine delivery systems prepared from biodegradable polymers has received considerable attention for past three decades. Immune response is a complex and intricately regulated sequence of events involving several types. Generally the immune response is triggered when an antigen enter the body. In the present report a comparative study on anti HBs and immunoglobulin titre of Wistar rats subjected to various types of treatment groups was carried out.

In the present study, a comparative evaluation on anti HBs and immunoglobulin titre of Wistar rats subjected to 
various types of treatment was carried out. In order to differentiate the status of anti body level after a single step immunization, certain groups of animals received booster dose with different combinations. The results tabulated in Table 1 represents a comparative studies on Anti HBs, IgG, IgA, IgM and IgE levels on $45^{\text {th }}, 90^{\text {th }}$ and $120^{\text {th }}$ day. From the results it is obvious that the anti HBs response on $45^{\text {th }}, 90^{\text {th }}$ and $120^{\text {th }}$ day after primary immunization without booster dose was found to be satisfactory with all the preparations (Table 1). From the Table 1 it is understood that significant anti HBs level was observed even up to $120^{\text {th }}$ day after a single dose of HBsAg encapsulated PLDEX microspheres. However, after booster dose either with PLDEX microspheres or with conventional vaccine showed elevated antibody level (Figure 1). In group 3 the specific immunoglobulin titre was high on $45^{\text {th }}$ day and slowly declines on $120^{\text {th }}$ day. It is note worthy that in group 4 alum adsorbed HBsAg was eliciting immune response more or less similar to group 1 but the level was lesser when compared. On the other hand, in group 5 a booster dose of alum adsorbed HBsAg was immunized and the level of anti HBs was measured. In this group, a robust immune response could be observed on $90^{\text {th }}$ day and declines on $120^{\text {th }}$ day.

Online with specific immunoglobulin titre, the IgG level also varies among the various treatment groups (Figure 2), it is understood that alum adsorbed HBsAg with booster dose in group 5 shown a better immune boost up when compared to the rest. However, lesser immunoglobulin titre was observed when alum adsorbed vaccine was administered as single dose (Table 1). Gutierro et al. [8] investigated the ability of BSA encapsulated PLGA microspheres to stimulate a specific $T_{h}$ cell subset. They determined the IgG2a/IgG1 ratio at weeks 3 and 5 for the highest oral and intranasal doses. They concluded that robust immunoglobulin production was observed after an injection of BSA encapsulated PLGA microspheres. In this study the immunoglobulin level was measured but sub typing was not performed. Maria Alonso et al. [9] investigated microencapsulated tetanus toxoid induced higher levels of IgG antibody and tetanus antitoxin activity than fluid tetanus toxoid. They stated that the levels were considerably higher than the estimated minimum protective levels in humans. This clearly demonstrated that microencapsulation of tetanus toxoid produced significant adjuvant effect. Simultaneously, sustained increased IgA titre was observed when HBsAg encapsulated PLDEX microspheres immunized with primary and booster dose in group 2 (Figure 3). The relative independence of the circulatory IgA is also evident for immune response induced by systemic [10]. Parenteral immunization with certain antigens induces strong IgA response in the circulatory compartment. The

Table 1. A comparative immunogenecity study.

\begin{tabular}{|c|c|c|c|c|c|c|c|c|c|c|c|c|c|c|c|}
\hline \multirow{2}{*}{$\begin{array}{c}\text { Group } \\
\mathbf{s}\end{array}$} & \multicolumn{3}{|c|}{ Anti HBs (IU/l) } & \multicolumn{3}{|c|}{ IgG (mg/dl) } & \multicolumn{3}{|c|}{ IgA (mg/dl) } & \multicolumn{3}{|c|}{ IgM (mg/dl) } & \multicolumn{3}{|c|}{ IgE (IU/dl) } \\
\hline & $45^{\text {th }}$ & $90^{\text {th }}$ & $120^{\text {th }}$ & $45^{\text {th }}$ & $90^{\text {th }}$ & $120^{\text {th }}$ & $45^{\text {th }}$ & $90^{\text {th }}$ & $120^{\text {th }}$ & $45^{\text {th }}$ & $90^{\text {th }}$ & $120^{\text {th }}$ & $45^{\text {th }}$ & $90^{\text {th }}$ & $120^{\text {th }}$ \\
\hline $\begin{array}{c}\text { Group } \\
1\end{array}$ & $\begin{array}{c}10.2 \pm \\
0.6\end{array}$ & $\begin{array}{c}11.3 \pm \\
0.3\end{array}$ & $\begin{array}{c}10.9 \pm \\
0.9\end{array}$ & $\begin{array}{c}793.6 \pm \\
2.4\end{array}$ & $\begin{array}{c}791.3 \pm \\
1.3\end{array}$ & $\begin{array}{c}792.6 \pm \\
1.2\end{array}$ & $\begin{array}{c}77.8 \pm \\
2.3\end{array}$ & $\begin{array}{c}78.8 \pm \\
2.6\end{array}$ & $\begin{array}{c}79 \pm \\
2.7\end{array}$ & $\begin{array}{c}85 \pm \\
2.2\end{array}$ & $\begin{array}{c}85.3 \pm \\
1.8\end{array}$ & $\begin{array}{c}88.1 \pm \\
2.7\end{array}$ & $\begin{array}{c}2.8 \pm \\
0.1\end{array}$ & $\begin{array}{c}2.9 \pm \\
0.2\end{array}$ & $\begin{array}{c}2.4 \pm \\
0.1\end{array}$ \\
\hline $\begin{array}{c}\text { Group } \\
2\end{array}$ & $\begin{array}{c}11.2 \pm \\
0.1\end{array}$ & $\begin{array}{c}12.3 \pm \\
0.1\end{array}$ & $\begin{array}{c}12.5 \pm \\
0.5\end{array}$ & $\begin{array}{c}798 \pm \\
1.5\end{array}$ & $\begin{array}{c}800.6 \pm \\
1.7\end{array}$ & $\begin{array}{c}802.5 \pm \\
2.7\end{array}$ & $\begin{array}{c}78.3 \pm \\
2.3\end{array}$ & $\begin{array}{c}80.3 \pm \\
2.2\end{array}$ & $\begin{array}{c}82.3 \pm \\
1.2\end{array}$ & $\begin{array}{c}86 \pm \\
2.1\end{array}$ & $\begin{array}{c}89.6 \pm \\
1.3\end{array}$ & $\begin{array}{c}89.8 \pm \\
2.1\end{array}$ & $\begin{array}{c}3.2 \pm \\
0.4\end{array}$ & $\begin{array}{c}3.2 \pm \\
0.4\end{array}$ & $\begin{array}{c}3.2 \pm \\
0.6\end{array}$ \\
\hline $\begin{array}{c}\text { Group } \\
3\end{array}$ & $\begin{array}{c}15.6 \pm \\
0.6\end{array}$ & $\begin{array}{c}15.3 \pm \\
0.1\end{array}$ & $\begin{array}{c}14.8 \pm \\
0.2\end{array}$ & $\begin{array}{c}794.3 \pm \\
1.4\end{array}$ & $\begin{array}{c}796.6 \pm \\
2.6\end{array}$ & $\begin{array}{c}796 \pm \\
3\end{array}$ & $\begin{array}{c}86.5 \pm \\
1.2\end{array}$ & $\begin{array}{c}83.8 \pm \\
1.2\end{array}$ & $\begin{array}{c}85.6 \pm \\
1.2\end{array}$ & $\begin{array}{c}94 \pm \\
1.3\end{array}$ & $\begin{array}{c}95.3 \pm \\
1.4\end{array}$ & $\begin{array}{c}93.1 \pm \\
1.4\end{array}$ & $\begin{array}{c}2.7 \pm \\
0.1\end{array}$ & $\begin{array}{c}2.8 \pm \\
0.3\end{array}$ & $\begin{array}{c}2.4 \pm \\
0.1\end{array}$ \\
\hline $\begin{array}{c}\text { Group } \\
4\end{array}$ & $\begin{array}{c}10.1 \pm \\
0.6\end{array}$ & $\begin{array}{c}10.9 \pm \\
1.3\end{array}$ & $\begin{array}{c}9.9 \pm \\
0.9\end{array}$ & $\begin{array}{c}793.6 \pm \\
1.7\end{array}$ & $\begin{array}{c}789.6 \pm \\
2.3\end{array}$ & $\begin{array}{c}786 \pm \\
3.2\end{array}$ & $\begin{array}{c}75.1 \pm \\
1.7\end{array}$ & $\begin{array}{c}77.3 \pm \\
2.1\end{array}$ & $\begin{array}{c}81 \pm \\
2.3\end{array}$ & $\begin{array}{c}80 \pm \\
1.6\end{array}$ & $\begin{array}{c}85.3 \pm \\
1.4\end{array}$ & $\begin{array}{c}85 \pm \\
1.5\end{array}$ & $\begin{array}{c}1.5 \pm \\
0.1\end{array}$ & $\begin{array}{c}1.5 \pm \\
0.4\end{array}$ & $\begin{array}{c}1.5 \pm \\
0.8\end{array}$ \\
\hline $\begin{array}{c}\text { Group } \\
5\end{array}$ & $\begin{array}{c}14 \pm \\
1.8\end{array}$ & $\begin{array}{c}16.9 \pm \\
1.2\end{array}$ & $\begin{array}{c}14.7 \pm \\
0.2\end{array}$ & $\begin{array}{c}874.6 \pm \\
1.6\end{array}$ & $\begin{array}{c}880.1 \pm \\
3.2\end{array}$ & $\begin{array}{c}877.8 \pm \\
0.4\end{array}$ & $\begin{array}{c}77.1 \pm \\
0.3\end{array}$ & $\begin{array}{c}77.6 \pm \\
2\end{array}$ & $\begin{array}{c}79.3 \pm \\
2.1\end{array}$ & $\begin{array}{c}79.3 \pm \\
2.2\end{array}$ & $\begin{array}{c}81.3 \pm \\
3.1\end{array}$ & $\begin{array}{c}81.5 \pm \\
2.5\end{array}$ & $\begin{array}{c}1.5 \pm \\
0.1\end{array}$ & $\begin{array}{c}1.5 \pm \\
0.4\end{array}$ & $\begin{array}{c}1.5 \pm \\
0.8\end{array}$ \\
\hline $\begin{array}{c}\text { Group } \\
6\end{array}$ & - & - & - & $\begin{array}{c}705 \pm \\
7.6\end{array}$ & $\begin{array}{c}708.3 \pm \\
7.9\end{array}$ & $\begin{array}{c}708.3 \pm \\
7.9\end{array}$ & $\begin{array}{c}70.1 \pm \\
0.5\end{array}$ & $\begin{array}{c}70.8 \pm \\
0.6\end{array}$ & $\begin{array}{c}70.6 \pm \\
0.8\end{array}$ & $\begin{array}{c}60.8 \pm \\
0.4\end{array}$ & $\begin{array}{c}61.8 \pm \\
0.5\end{array}$ & $\begin{array}{c}62.6 \pm \\
0.6\end{array}$ & $\begin{array}{c}1.5 \pm \\
0.3\end{array}$ & $\begin{array}{c}1.5 \pm \\
0.4\end{array}$ & $\begin{array}{c}1.6 \pm \\
0.5\end{array}$ \\
\hline $\begin{array}{c}\text { Group } \\
7\end{array}$ & - & - & - & $\begin{array}{c}705.8 \pm \\
2.1\end{array}$ & $\begin{array}{c}710.3 \pm \\
1.6\end{array}$ & $\begin{array}{c}709.5 \pm \\
1.4\end{array}$ & $\begin{array}{c}70.6 \pm \\
0.8\end{array}$ & $\begin{array}{c}72.6 \pm \\
1.1\end{array}$ & $\begin{array}{c}72.5 \pm \\
1.7\end{array}$ & $\begin{array}{c}83.3 \pm \\
1.3\end{array}$ & $\begin{array}{c}83.6 \pm \\
1.7\end{array}$ & $\begin{array}{c}86.5 \pm \\
1.7\end{array}$ & $\begin{array}{c}0.8 \pm \\
0.1\end{array}$ & $\begin{array}{c}0.9 \pm \\
0.2\end{array}$ & $\begin{array}{c}0.7 \pm \\
0.3\end{array}$ \\
\hline
\end{tabular}

Group 1-Immunized with a single dose of hepatitis B vaccine encapsulated PLDEX microspheres, Group 2-Immunized with hepatitis B vaccine encapsulated PLDEX microspheres as primary dose and the same as booster dose, Group 3-Immunized with hepatitis B vaccine encapsulated PLDEX microspheres as primary dose and conventional alum adsorbed hepatitis B vaccine as booster dose, Group 4-Immunized with a single dose of alum adsorbed hepatitis B vaccine, Group 5-Immunized with alum adsorbed hepatitis B vaccine as primary dose and the same as booster dose, Group 6-Control animals (without vaccines), Group 7-Control samples with dummy PLDEX microspheres. By performing Dunnet multiple comparison test each value is a mean of 6 batches with a standard deviation and all the values were significant $(P<0.05)$. 


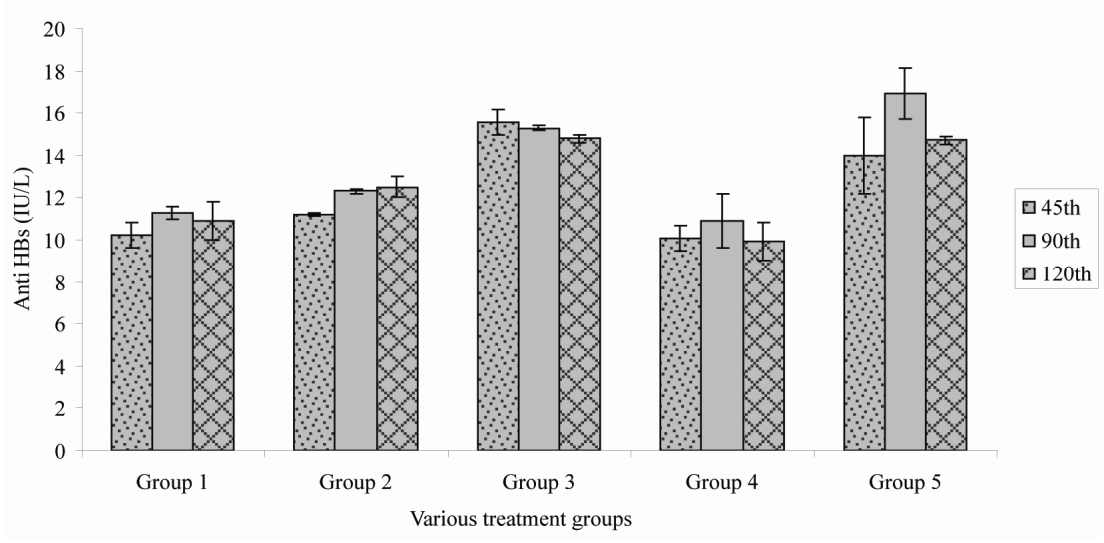

Figure 1. Anti HBs titre level of various treatment groups.

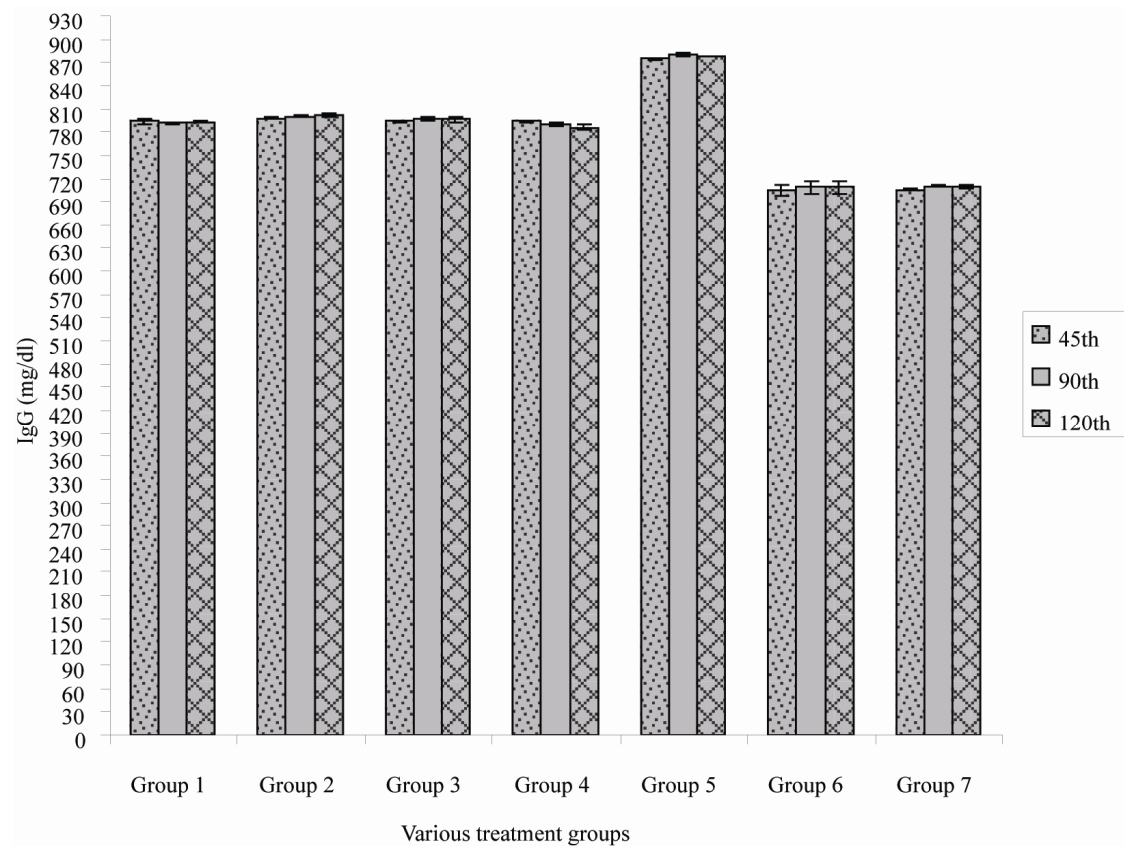

Figure 2. Immunoglobulin G (IgG) titre of various treatment group.

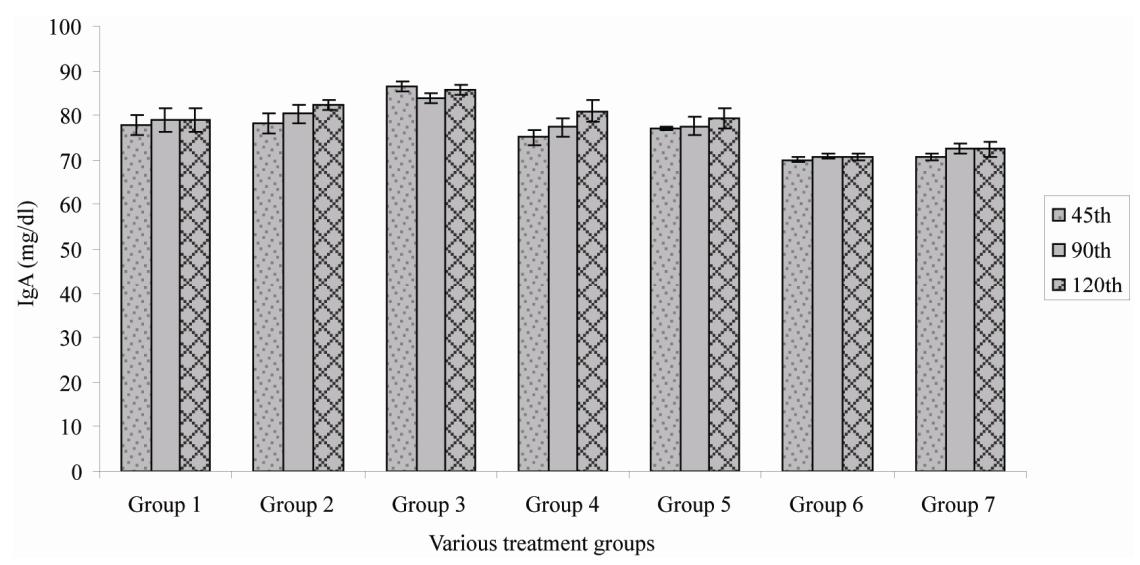

Figure 3. Immunoglobulin A (IgA) titre of various treatment groups. 
origin of serum IgA antibodies specific for parenterally introduced antigens remains unclear, but regional lymphnodes and spleen are probably involved. In this research work it is known that significant IgA antibody was produced, suggesting that the release of IgA antibody was due to the local action after forming depot atthe site of injection. The route of immunization and types of antigens that might induce an effective immune response in human bone marrow has not been clarified. However, specific IgA antibody that is initially polymeric appears in serum of parentally immunized or mucosally infected individuals, irrespective of the type of antigen. In this study significant IgM antibody was produced by polymeric microspheres either with a single dose or with booster dose. This might be due to the direct trigger of B lymphocytes and no immunological memory was effected. In this research work the IgE level was measured in order to ascertain the hypersensitivity of HBsAg encapsulated PLDEX microspheres. However, the microparticulate vaccine was able to induce lesser production of IgE but dummy microspheres did not elicit significant IgE level. Moreover, the total system did not produce any skin rash at the site of the injection. From this, it is understood that PLDEX microspheres were highly biocompatible in the biological system. Therefore, it is understood that the total immune system is actively participated to elevate acquired immunity either as a single dose or with booster of various combinations.

\section{Acknowledgements}

The authors are grateful to Serum Institute of India, Pune for providing hepatitis B vaccine.

\section{REFERENCES}

[1] M. R. Hilleman, "Vaccines in Historic Evolution and Perspective: A Narrative Vaccine Discoveries,” Vaccine, Vol. 18, No. 15, 2000, pp. 1436-1447. doi:10.1016/S0264-410X(99)00434-X

[2] M. A. Kane, "Global Status of Hepatitis B Immunization,” Lancet, Vol. 348, No. 9029, 1996, p. 696.

\section{doi:10.1016/S0140-6736(05)65598-5}

[3] T. Joseph and L. Stephen, "Antiviral Chemotherapy for the Treatment of Hepatitis B Virus Infection,” Gastroenterology, Vol. 118, No. 2, 2000, pp. S83-S103. doi:10.1016/S0016-5085(00)70008-4

[4] P. R. Perrillo, W. Teresa, R. Jorge, L. Gary, S. Eugene, G. Robert, M. Paul, D. Jules, A. Paul, D. Rolland, A. Gaya, B. Steve, C. Lynn and B. Nathaniel, “A Multicenter United States-Canadian Trial to Assess Lamivudine Monotherapy before and after Liver Transplantation for Chronic Hepatitis B,” Hepatology, Vol. 33, No. 2, 2001, pp. 424-432. doi:10.1053/jhep.2001.21554

[5] L. A. Moyer and E. E. Mast, "Hepatitis B: Virology, Epidemiology, Disease, and Prevention, and an Overview of Viral Hepatitis," American Journal of Preventive Medicine, Vol. 10, 1994, pp. 45-55.

[6] S. Tazio, K. M. Thomas, S. Gabriela and J. Pal, "Immunity in Response to Particulate Antigen Delivery Systems," Advance Drug Delivery Revew, Vol. 57, No. 3, 2005, pp. 333-355. doi:10.1016/j.addr.2004.09.008

[7] F. U. Karen, H. Roy, Z. Kim, U. M. Christina, A. Jaklenec, J. Frazier, L. Noah, B. Paul, M. K. Alexander and L. Robert, "A Potential Approach for Decreasing the Burst Effect of Protein from PLGA Microspheres," Journal of Pharmaceutical Sciences, Vol. 92, No. 8, 2003, pp. 15821591. doi:10.1002/jps.10414

[8] I. Gutierro, R. M. Hernandez, M. Igartua, A. R. Gascon and J. L. Pedraz, "Influence of Dose and Immunization Route on the Serum IgG Antibody Response to BSA Loaded PLGA Microspheres," Vaccine, Vol. 20, No. 17-18, 2002, pp. 2181-2190. doi:10.1016/S0264-410X(02)00146-9

[9] J. M. Alonso, K. R. Gupta, M. Caroline, R. G. Siber and L. Robert, "Biodegradable Microspheres as ControlledRelease Tetanus Toxoid Delivery Systems,” Vaccine, Vol. 12, No. 4, 1994, pp. 299-306. doi:10.1016/0264-410X(94)90092-2

[10] M. W. Russell, C. Lue, W. Van den Bake, Z. Moldoveanu and J. Mestecky, "Molecular Heterogenicity of Iga Antibodies during an Immune Response," Clinical \& Experimental Immunology, Vol. 87, No. 1, 1992, pp. 1-6. doi:10.1111/j.1365-2249.1992.tb06404.x 